Revista de la red interuniversitaria de estudios sobre las literaturas rioplatenses contemporáneas en Francia

$14 \mid 2016$

Levrero

\title{
Las puertas de Levrero
}

Julio Premat

\section{OpenEdition}

Journals

\section{Edición electrónica}

URL: http://journals.openedition.org/lirico/2269

DOI: $10.4000 /$ lirico.2269

ISSN: 2262-8339

Editor

Réseau interuniversitaire d'étude des littératures contemporaines du Río de la Plata

\section{Referencia electrónica}

Julio Premat, «Las puertas de Levrero », Cuadernos LIRICO [En línea], 14 | 2016, Puesto en línea el 07

junio 2016, consultado el 20 abril 2019. URL : http://journals.openedition.org/lirico/2269 ; DOI :

10.4000/lirico.2269

Este documento fue generado automáticamente el 20 abril 2019.

\section{(c) (i) (9)}

Cuadernos LIRICO está distribuido bajo una Licencia Creative Commons Atribución-NoComercialSinDerivar 4.0 Internacional. 


\title{
Las puertas de Levrero
}

\author{
Julio Premat
}

1 La obra de Mario Levrero se expande en una dinámica entre el adentro y el afuera. Es decir, del adentro (cuarto, casa, ciudad, mente, sueño, imaginario) a un afuera inhóspito, indeterminado, perturbador y también, inversamente, desde lo abierto, absurdo y llano, hacia un refugio improbable, una construcción anhelada, un regreso fuera de alcance, todo ello en un movimiento constante y sin embargo intrascendente en cuanto a objetivos y logros se refiere. Ese par, adentro/afuera, significan alternativamente espacio propio y espacio público, lo visible y lo oculto, lo consciente y lo inconsciente, lo real y lo deseado, la carencia y la búsqueda o, por qué no, la página en blanco y la escritura (el silencio y la palabra, el vacío y el significado). Salir, entrar, pasar, decir, buscar, desear, sondear, escribir, dudar en los umbrales, son, por lo tanto, las acciones más a menudo repetidas.

En la primera parte de la obra (la llamada Trilogía involuntaria más algunos cuentos y relatos), ese movimiento se focaliza en una construcción espacial, de raigambre kafkiana, en la cual la casa, en tanto que metáfora recurrente de la mente humana, es la imagen dominante. En la última parte (El discurso vacío, La novela luminosa, pero también sus anuncios, es decir los diarios incluidos en El portero y el otro), la dinámica pierde sus oropeles ficcionales, sus ladrillos, puertas, ventanas y techos, no sólo porque son relatos de un encierro, sino porque se concentran en la investigación, el buceo, cuando no en la exhibición de una "profundidad». De esa profundidad personal, íntima (o de una superficialidad absoluta y neutra, lo que paradójicamente resulta, en este caso, ser similar), tendría que surgir, que salir, que irrumpir, la palabra literaria. Así, obsesivamente, los diarios de Levrero recorren una exterioridad pobre, vacía -un discurso vacío-, como modo de circunscribir una interioridad interrogada y revisada.

3 Entre las múltiples posibilidades que el mecanismo, así resumido, presenta, elijo una imagen metafórica (la puerta) y una posición imaginaria (el escritor en el umbral de la escritura), para recorrer esos polos de la producción levreriana que, en muchos sentidos, puede ilustrar una obsesión contemporánea con el inicio, la exposición de los mecanismos de escritura, lo inacabado, la intimidad de la creación y los terrores ante un tiempo incomprensible. 
La novela luminosa, libro póstumo y sin duda punto de referencia ineludible para acercarse a la obra del uruguayo, incluye la escritura de un comienzo repetido hasta el paroxismo, la meticulosa narración sobre una posposición y, en esa perspectiva, una autoedición de materiales genéticos, variantes y borradores. Para comentar esos rasgos dominantes remonto a los primeros textos, retomando entonces algunas puertas inaugurales. El gesto permitirá interrogarse, también, sobre la periodización ya establecida de la producción. Porque si los cambios en la trayectoria del escritor son evidentes y a veces enigmáticos (leyendo sus libros uno no puede sino preguntarse cómo el mismo autor pasa de las kafkianas construcciones de la Trilogía -La ciudad, El lugar, París- a una especie de picaresca policial -Nick Carter... o Dejen todo en mis manos- y a una práctica peculiar del diario íntimo y del vacío), el contrapunto entre algunos textos tempranos y La novela luminosa despeja, creo, esta impresión inicial de disparidad. Parto de la hipótesis que hay una coherencia imaginaria en el conjunto (ya Verani no veía contradicciones entre el período " realista » y el período "fantástico ", en tanto que remiten a capas diferentes del ser) ${ }^{1}$, y que esa coherencia tiene que ver con ciertos atributos asociados desde los primeros textos al comienzo de la escritura, al inicio del tiempo y a las representaciones de la expansión narrativa.

O, en todo caso y en el fondo es lo mismo, la hipótesis seria pensar que la irrupción de un texto tan extremado como La novela luminosa crea, retrospectivamente, una coherencia desde los comienzos, o vuelve visible una supuesta determinación en los inicios mismos de la obra. La perspectiva permite abarcar un doble objetivo : por un lado leer la peculiar problemática del comienzo de escritura y del relato de creación en La novela luminosa y, segundo, analizar los beginnings de un escritor desde el cierre insólito de su obra, un fin hecho de un sinfín de comienzos.

\section{Puertas simétricas. El lugar.}

...esta vez sí, la puerta se abrió. Me encontré ante una nueva oscuridad.

Empecemos por el principio. Por uno de los principios. El lugar, en El lugar, se define como un espacio onírico, inversión del espacio diurno al que se pasa de manera inexplicable, desde cualquier situación banal de la vida cotidiana. Actualizando un tópico de los íncipits narrativos y de la metaforización de la escritura, ese paso tiene lugar, en lo que concierne al protagonista, en el momento del despertar (despertar : desaparición de un mundo y aparición de otro, analogía que fue incluso utilizada para comentar el Génesis; " atardeció y amaneció el día primero » leemos, antes de que sea creado el día, con la existencia del sol). Las puestas en escena del cruce o traslado son, según se lo va progresivamente sugiriendo en la novela, el fruto del inconsciente, de los deseos y de las fantasías de cada personaje; en algún momento dado, uno de ellos emite inclusive la hipótesis de que las características en sí de los lugares dependen de quién las soñó. Se trata entonces de un espacio idealista en el que se combinan y mezclan, inextricablemente, los sueños de todos los personajes -y, en regla general sus pesadillas-. Es lo que postula, sin certezas, el Francés : se trata de una nube o algo así de «materia especial» que da forma «a nuestros deseos o temores inconscientes»; por eso los diferentes modos en que los personajes llegan allí "parecieran corresponder a la personalidad de cada uno » (102) ${ }^{2}$. Las reglas de paso de un nivel a otro son ésas.

7 El lugar cambia a lo largo de la novela. Primero aparece con los rasgos dominantes del encierro y de una estructura persecutoria : esa serie de piezas simétricas que se recorren 
como se recorre el tiempo, sin poder jamás volver atrás, y en las cuales el avance conlleva, también como en una vida humana, una inevitable degradación y ruina : la sucesión de puertas y habitaciones marcan el transcurso temporal. Ese lugar delimitado y repetitivo se va abriendo : una playa para una escena de felicidad con tintes eróticos, un campo en el borde de una selva, un paisaje campestre que invita a una vida familiar serena. Al final, la totalidad del espacio termina coincidiendo con el punto de partida, es decir la ciudad de la vida despierta : lo que era el afuera en el comienzo de la novela se convierte en un gigantesco adentro; lo que fue lo « real ", se vuelve mapa de las pesadillas de todos sus habitantes. (Real, adentro, afuera : al respecto, recordemos que Lacan se pregunta si, en una muralla que diese la vuelta al mundo, se abre una puerta, adónde estaría el adentro y adónde el afuera).

El largo recorrido por el otro lado de lo conocido termina desembocando en el regreso a lo mismo, pero un "mismo" que cambió de signo: ahora la vida diurna contiene el carácter persecutorio, absurdo y torturante de las pesadillas. Una alusión a Kafka, a modo de guiño, enmarca intertextualmente estas características («se trataba de un juicio, en el que yo era el acusado » (43) es el lacónico resumen de un sueño que funciona como una lectura onírica de $E l$ proceso). Por otro lado, en El lugar como en sus primeros textos, Levrero comparte con Cortázar la obsesión del «pasaje », la atribución de un valor existencial al gesto y, con más agudeza todavía que el argentino, el descubrimiento que al proyectar imaginarios y deseos en ese « otro lado", se construyen monstruos, terrores y riesgos mortíferos.

El movimiento central y el anhelo fundamental para el protagonista serán entonces salir, aunque sus salidas son imposibles, fracasadas o no hacen sino ampliar el «afuera » en tanto que un gigantesco « adentro », como vimos. El dispositivo de paso del protagonista de su mundo normal a ese espacio y sus reacciones tienen que ver con eso: en las primeras páginas, después de un despertar hecho de extrañamiento y de amnesia, se encuentra en una habitación desconocida en la que descubre una puerta. Puerta cerrada, causa inmediata de vagos pensamientos regresivos: no sabe si abrirla porque, del otro lado, quizás haya gente haciendo « alguna actividad » que su presencia pudiera molestar (17). A esa puerta primera, la que tal vez le estaba destinada (si retomamos el « Ante la ley » de Kafka), no la logrará abrir ni podrá ver nada por el agujero de la cerradura. En cambio, enfrente y como en un reflejo, hay otra puerta, que sí se abre y lo lleva a una «nueva oscuridad». El envión que propulsa la narración de la novela es el hallazgo de una puerta, si se lo puede decir así, de reemplazo; la otra, la quimérica, la del inicio, queda para siempre cerrada, fuera de alcance. La puerta es una entrada, una frontera, un marco de posibilidades, una prohibición transgredida. Es, también, una opción de sustitución que lleva al relato -a la peripecia-, sin que la verdadera puerta, la primera, haya sido abierta : por ella no se puede entrar.

10 Así se define otro principio de funcionamiento, muy operativo en la primera parte: la repetición. No sólo la puerta refleja otra puerta, sino también la habitación en la que entra «repite exactamente» la anterior. El movimiento en sí es inútil porque la dicotomía entre adentro y afuera parece haberse quebrado : salir y entrar son lo mismo. Una serie de pasos de una pieza a otra, compulsivos, no hacen más que marcar cierto inmovilismo; los intentos de enfrentar una dificultad de pesadilla se diluyen en una ineficacia, en una detención dinámica. Sin embargo, esa repetición conlleva una tercera idea, la del paso sin retroceso, ineluctable como el del tiempo, dijimos. No se puede volver atrás, sólo se puede avanzar en una dirección. Aunque sea mínima, cada paso de una 
habitación a otra, supone una pérdida en la medida en que no hay retroceso ( « sentí como si hubiese perdido algo valioso ») (22).

11 Su primera reacción ante esta situación es la de un dolor extremado (convulsiones, llanto) y luego una apatía, cansancio, melancolía, adormecimiento. Este estado le preocupa (" pronto habría de sentirme muy mal») (46) por lo que decide modificar su conducta. La decisión de resistir alcanza para que, mágicamente, una variante se produzca : en la pieza siguiente hay gente y luz. Por un instante, el protagonista vive la tentación de la depresión, del inmovilismo ante la puerta por abrirse y la convicción de que, del otro lado, hay más de lo mismo. Esta situación de detención apática y de imposibilidad de acción, aquí fugaz, se volverá permanente al final de la obra («Diario de un canalla », El discurso vacío, «Diario de una beca » en La novela luminosa).

El paso, la repetición, la pérdida, giran previsiblemente alrededor de lo sexual. Al comienzo, hay muchas referencias a Ana: mujer deseada, mujer entrevista o prometida, aunque afirme al final que no podrá aproximarse a ella ni a ninguna otra mujer, ya que sólo utilizaba su imagen para "olvidar la soledad, para evadirme de este ser que me habita, que me odia, que me obliga a actuar en contra de mí mismo». Temática prolongada con la mujer andrógina (Mabel), y Alicia, la mujer encontrada, poseída y que implica una ineluctable frustración. Valga la evidencia : Ana, nombre que es también el de otra mujer deseada en La ciudad, Alicia, Angeline -en París-, son todas mujeres de comienzo, mujeres con A (mientras que la andrógina Mabel lleva su ambigüedad -y su belleza- al final de su nombre), nombres y características que van a repetirse en obras posteriores. Por el momento, el encuentro con Mabel le produce una fuerte excitación, inclusive una erección que, luego, se vuelve otra cosa, la «corriente » que le atraviesa el cuerpo " pasa a transitar por otras vías ", lleva a un estado de gran dulzura y lucidez, a la impresión de una humanidad plena («me sentí realmente un hombre »), integrado en la " Naturaleza ", como una " partícula ínfima y sin embargo imprescindible del Universo » (60). Sentimiento cósmico, oceánico (diría Freud), que anticipa lo que Levrero denominará « experiencias luminosas » años más tarde ${ }^{3}$.

En otros términos, puede verse el dinamismo permanente del personaje, hecho de un deseo imperioso por «salir » como una búsqueda de aquello que está más allá, de la vida humana, de lo posible ; el afuera, inalcanzable, abierto y luminoso, sería el espacio de la trascendencia. Al mismo tiempo, la llegada a la ciudad se acompaña con el episodio más onírico y confuso de la novela, episodio de claros tintes sadomasoquistas y homosexuales en donde el protagonista ocupa sucesivamente el lugar del torturador y el del torturado, en el borde inenarrable de una castración o en el de un contacto genital impensable (al final del episodio, mientras el bisturí recorre verticalmente su pecho, «una cosa húmeda » se apoya en su vientre, hasta que una serie de explosiones lleva a un derrumbe general). O sea lo que, de nuevo, siguiéndolo a Levrero, podría calificar al episodio de una experiencia -de una novela- oscura.

Retomando. El sueño, a la vez fuente de narración y repertorio de formas. La escritura como el abandono de lo « real», sus pactos de verosimilitud y de creencia, para hundirse en peripecias y mundos oníricos. La ficción como un angustiado movimiento de puerta en puerta y de habitación en habitación, con un doble movimiento de empuje de la ficción y de intento de, gracias a ella, "salir »: si se quiere, un intento de entender, descifrar, explicar. La búsqueda, a través del movimiento narrativo, de otro lugar, de otra vivencia, que anulen las contradicciones entre realidad y sueño, en particular entre lo deseado y lo poseído. Por último, una espacialización de la vida psíquica, es decir la materialización en 
lugares de sentimientos, angustias, deseos (la «figurabilidad» del sueño en Freud). El espacio en El lugar está construido directamente a partir de estas ideas, y de la pesadilla de encontrarse encerrado en él.

El lugar no es el primer relato (lo es "Gelatina ») y ni siquiera la primera novela de Levrero (La ciudad, la precede). Con todo, forma parte de los beginnings del autor y vuelve visibles algunos procedimientos y obsesiones imaginarias que, más allá de la tonalidad kafkiana de estas ficciones, se repiten en los libros posteriores. Ahora bien, yo podría haber respetado aquí esta cronología y comenzado por el íncipit de « Gelatina », en el cual las «náuseas" producidas por la primera bocanada de humo al despertar empujan al narrador al movimiento -y al pleonasmo- : «Salí afuera. » ${ }^{4} \mathrm{O}$ retomar el de La ciudad ( $" \mathrm{La}$ casa, al parecer, no había sido habitada ni abiertas sus puertas y ventana durante muchos años ») y la inmediata mención de una puerta que permite acceder a la degradación de ese espacio primario, regresivo, hecho de una interioridad somática: «Quizá antes de entrar, en el momento de abrir la puerta, noté la humedad, las paredes el techo goteaban, todas las cosas estaban húmedas, como cubiertas de baba, el piso resbaloso.» La imposibilidad de habitar, "aunque más no fuera de forma precaria, la casa » lleva al desplazamiento, al viaje, a la novela que empieza ${ }^{5}$. Entrar, salir y narrar se superponen.

Sin embargo, la primera parte de El lugar cristaliza ciertas constantes. Ya se sabe : el comienzo no es sólo el primer texto sino también aquel que ofrece posibilidades que serán más obsesivamente desarrolladas y que, por lo tanto, aparece a posteriori como anunciador. Aquí se percibe algo específico en términos formales y temáticos, esa búsqueda de lo que Martín Kohan identifica como un gesto compulsivo y repetitivo en toda la obra, la salida. Cualquier salida a la calle se vuelve una aventura y hay un mandato de lanzarse hacia afuera, de dejar la casa, es decir, escribe Kohan, dejar esas «casas deshabitadas, invadidas, expulsivas, que acaban por derrumbarse, desplomarse, destrozarse o que están casi en ruinas"6. Opuesto pero no contradictorio sería ver en las proliferantes puertas de la primera parte de El lugar, una forma-relato, tanto en el sentido de lo que lanza la acción, el acontecer, la confrontación del sujeto con la otredad, como una materialización metafórica del misterio (y para empezar, el enigma de lo sexual), de lo prohibido, de lo que se repite sin alcanzar una consistencia reveladora. Lugar de paso y de repetición, de veda y posibilidad, de encierro y comienzo, la puerta es, en Levrero, lo que el puente y el pasaje son en Cortázar. En todo caso, abrir, no la primera puerta, dijimos, sino la otra, su reflejo, es comenzar : la narración, la búsqueda, el movimiento hacia un sentido que está a la vez «afuera " y en el centro, en lo más denso del mundo inconsciente e ignorado. Valéry describía el comienzo de escritura como una escapada milagrosa fuera de un mundo cerrado, el de las representaciones mentales, y una introducción en el universo de los hechos ${ }^{7}$. En Levrero la frontera mundo cerrado/ universo de los hechos está, en varios sentidos, borroneada. 0 el comienzo de escritura se da y se prolonga en la dialéctica de lo cerrado y lo abierto, de lo mental y lo escrito.

Ahora bien, y el lector, ¿cómo « sale » de ese lugar? ¿Cómo termina eso que no hizo sino empezar? La última frase de la novela apunta : «Los interrogantes se siguen sucediendo, mis manos siguen escribiendo, pero no surge ninguna respuesta. " Las puertas se abren, se repiten, pero lo único posible es encontrar, del otro lado, lo mismo, con la leve diferencia de que ahora existe el relato : al narrarlo, el protagonista está allí y ya no allá. El avanzar de puerta en puerta es seguir escribiendo, es seguir sucediendo, sin finalidad ni ilusiones. Es comenzar, recomenzar, con imprecisión y angustia: "Hacía ya unos cuantos días que la angustia trazaba en mí nuevos dibujos, con la imprecisión 
característica de los comienzos » (103). No estamos tan lejos, después de todo, de La novela luminosa.

\section{Puertas oscuras. Desplazamientos.}

Más que el pasado, tendía, ahora, a añorar el presente; y comprendí que no se trataba de añorarlo, sino de luchar minuto a minuto para obtenerlo.

Desplazamientos: el título de la novela de Levrero (primera edición en 1987) puede interpretarse o declinarse en tres órdenes distintos. Primero, en tanto que el motor de la intriga, vale decir los movimientos, limitados pero constantes, que efectúa el narrador dentro de la antigua casona familiar a la que ha acudido para cobrar los alquileres de los múltiples inquilinos que allí residen. Otra vez en casa -en una casa-, otra vez una intriga en movimiento. No es un viaje ni implica un dinamismo importante, pero cierto es que la narración va de habitación en habitación, como múltiples decorados de teatro o como fragmentarias secuencias narrativas. Cambian los personajes, cambian los ambientes y también las situaciones y peripecias. No hay una historia única ; el argumento se desplaza.

El segundo orden aludido por el título tiene que ver con la utilización freudiana del término, o sea con uno de los principios de transformación del material latente por el trabajo de sueño, también operativo en el síntoma : el desplazamiento de " acento, interés o intensidad $»^{8}$, entre los diferentes elementos presentes (referencia que habría que comentar junto con el epígrafe, una cita de, nada menos, Jung)``. Así, en tanto que posición defensiva y expresiva al mismo tiempo (se disimula y se transmite desde otro lugar), las emociones se ven disociadas de los objetos o representaciones consideradas peligrosas, inaceptables y atribuidas a otros elementos. Una energía que, desligada de lo que la engendra, se desplaza por vía asociativa hacia objetos secundarios o periféricos. Esta perspectiva nos invita a leer en la novela los desplazamientos argumentales y espaciales tanto como los vaivenes de una narración que, veremos, "se arrepiente », vuelve atrás y elige otras direcciones, otros objetos, otras representaciones- como una exposición inédita de lo que cabe denominar el mecanismo de producción de lo onírico, en particular de la intervención de la censura. El hecho de que Levrero haya considerado esta historia como la «novela oscura » opuesta a la «novela luminosa », y que en el relato se repitan situaciones a la vez regresivas e intensamente fantasmáticas, parecen corroborar esta hipótesis de lectura. El paso, sin solución de continuidad, entre el sueño y la vigilia, mecanismo frecuente en Levrero, asocia aquí, una vez más, escritura y vida onírica.

Tercer orden, lo narrativo; en contradicción con las determinaciones que impone en el relato lo ya escrito, la intriga, inexplicablemente, vuelve atrás una docena de veces y cambia. Es decir que, como en un rebobinado cinematográfico, la enunciación retoma párrafos anteriores y, a partir de ellos, la situación que había empezado a desarrollarse modifica su rumbo, recorriendo otras posibilidades. Las reorientaciones y variaciones así incluidas son a veces trazados paralelos de opciones, siguiendo el ideal leibniziano imaginado por Borges en «El jardín de senderos que se bifurcan» (en una opción, el protagonista agrede sexualmente a la mujer deseada; en otra, está tentado de hacerlo pero se abstiene, etc.). Estas alteraciones funcionan otras veces como interrupciones de la intriga, creando un efecto de exhibición del procedimiento o de escritura a la vista, dándole al relato una forma de proliferación y arborescencia, en desplazamiento constante hacia lo lateral, si puede expresárselo así, en vez de progresar, todo lo cual 
pone en duda los imperativos de lo lineal y de lo ineluctable de lo ya sucedido, tanto como de la cronología y de la organización causal.

21 Comentado el título, umbral idóneo para la presentación del relato, leamos el texto a partir de esos tres órdenes sugeridos. $Y$ ya que de comienzos se trata, entremos en la novela a partir de una larga cita, el íncipit completo :

La casa tiene un típico olor a frituras y hacinamiento, una constante en estas recorridas de principio de mes. Aquí me resisto a golpear la puerta o pulsar el timbre; utilizo la llave. Es, después de todo, la casa de mi infancia, mi casa, y todavía conserva muchas cosas mías. Pero ese gesto no me resulta fácil ; sé que estoy invadiendo un territorio que ahora es ajeno, aunque ellos, en su promiscuidad, no puedan juzgar mi actitud. Me muevo con cierto envaramiento, con algo de sospechosa cautela, por ése y por otros motivos -como el deseo insolente, insidioso, casi morboso por una de las pensionistas; o las formas complejas de odio, porque está casi en ruinas, hacia esta misma casa que amo, y hacia mi padre, porque murió y me dejó esta herencia de sus eternos recorridos de principios de mes, de su avaricia y de su rol de avaro; y hacia mí mismo por representar este papel o por mis inútiles rebeldías : el viejo se murió de golpe y me enfrentó a mi propia cobarde impotencia, me partió en dos mitades, una que rasca los bolsillos de la pobre gente, otra que quisiera ser libre. (113) ${ }^{10}$

Un íncipit, como se ve, inestable, acorde con lo dicho. En términos argumentales, la novela gira alrededor de algunas líneas temáticas obsesivamente repetidas, y combinadas en este párrafo : otra vez una casa en decadencia, que huele a frituras y a hacinamiento, y en ella, otra vez, lo sexual. El desplazamiento por el edificio es de mujer en mujer y está marcado por irrupciones del deseo, un deseo a veces precedido por fantasías recurrentes ; una de esas mujeres, Nadia, siempre acompañada por una beba recién nacida y presentada varias veces con leche en los pezones desnudos, es una especie de ideal sexual, amor imposible, imagen que, en alguno de los circuitos narrativos, es incluso una figura casi mítica (« quintaesencia de la femineidad, un ser con mucho de mitológico ») (164). Es ella la que despierta ese "deseo insolente, insidioso, casi morboso». En otros casos, el deseo surge sin anuncios previos y ciertas relaciones sexuales ocurren por sorpresa, es decir, por sorpresa para el propio personaje, porque de pronto emerge en él una carga pulsional ante configuraciones fantasmáticas imprevisibles. Así, las idas y vueltas por los corredores húmedos y decrépitos de lo que fue otrora la casa de infancia, son un desplazamiento en zonas conocidas pero también en las desconocidas del deseo. Una pulsión tan imperiosa como problemática: su expresión o su realización conllevan desilusión y angustia; si el «velo fantasmagórico » de una escena excitante se esfuma, surgen « niveles insoportables de angustia » (175). En efímeros momentos, desaparece el deseo dando lugar de nuevo a una placidez cósmica, sensación que se asemeja a lo que Levrero llamará más tarde "experiencias luminosas ». Se entiende, cotejándolas con las violentas, hacinadas y turbias pulsiones infantiles que dominan el texto, que Desplazamientos sea o pueda ser aquella « novela oscura » denostada.

$23 \mathrm{Y}$, significativamente si tomamos en cuenta el resto de la producción de Levrero, esta estructura, que intenta plasmar lo libidinal, se articula en el paso de una pieza a otra, en la repetida y a menudo conflictiva confrontación con puertas cerradas, problemas de llaves (perdidas, recuperadas), temores por lo que encontrará del otro lado. En el íncipit leído: dudas entre golpear o no, consecuencias previsibles del hecho de utilizar la llave, gesto nada fácil y juzgado por los demás; dudas y mirada exterior que van a repetirse a lo largo del texto (¿Cómo entrar? ¿Qué pensarán si lo hago ? ¿Qué pasará entonces ?). La representación del espacio narrativo en tanto que equivalentes alegóricos de lo 
consciente y lo inconsciente se lleva a cabo, de manera relativamente clásica, por la de una casa extensa, de formas imprecisas y laberínticas, en la que un sujeto va descubriendo, con temor y deseo a la vez, zonas ignoradas, cuartos prohibidos, resabios del pasado. «Casa tomada », ya se sabe.

Notemos también que, con insistente repetición, se alude a la dimensión de regreso, si no de regresión, que tiene esa visita : se trata, como queda dicho, de la casa de infancia y esa dimensión digamos infantil o anterior está presente en afirmaciones y contenidos explícitos. La casa "conserva muchas cosas mías» se anuncia en el íncipit, luego el protagonista duerme en el medio de los objetos que quedan de su familia y encuentra algún juguete de la niñez. Y, constantemente, se sitúa en un doble plano : lo que la casa es ahora y lo que fue. El desplazamiento gira en ese ámbito, entre lo decible y lo no decible de esos contenidos reencontrados. Otra cita : «...una casa que en mi memoria tenía el tamaño y la importancia de un templo arquetípico; la casa ha revivido al niño que me habitaba y ahora este niño se siente desconcertado, culpable y temeroso » (127).

Pero lo regresivo del relato también surge en lo que podría llamarse un repertorio de motivos que, gracias a una referencialidad psicoanalítica, se nos invita a identificar con fantasmas o sentimientos primitivos : atracción por figuras maternas, temor de las figuras masculinas, obsesión por la escena originaria, alternancias de excitación y de culpas intrusivas, retorno de lo reprimido, censura superyoica, sacralización de lo infantil (en la cita anterior: "el templo arquetípico»), etc. El desplazamiento en la casa es una topografía de los deseos de la infancia, en donde una multiplicidad de indicios apunta a la revelación supuesta del «nudo » o fantasma originario. En ese sentido y completando de lo dicho, la visita a la casa es una prolongación de la herencia paterna (en el íncipit : « me dejó esta herencia de sus eternos recorridos de principios de mes») pero también la imposición de un parecido ( «su avaricia») : está allí ocupando el lugar del padre, de un padre que, en alguna medida, lo acompaña en la visita (el narrador ve en su sombra el perfil del padre y los inquilinos aluden constantemente al " antiguo » propietario con hostilidad) (p.e. 140). Un padre hacia el cual el narrador afirma un odio explícito. Una herencia y una identificación rechazadas, que van a la par de una visión desdoblada del protagonista («me partió en dos mitades»). En varias articulaciones del relato él se ve a sí mismo escindido, múltiple, tal cual lo es su comportamiento siguiendo el sistema narrativo de avances, retornos y modificaciones de los actos realizados. En resumidas cuentas, afirma Levrero, es una novela que él intentó escribir a partir de su " sombra », lo que le llevó «mucha introspección » ("por eso nadie la soporta», agrega). Una sombra que para él es real, como « un planetita siempre en oposición al planetita llamado yo, de modo tal que desde el yo uno nunca la puede percibir directamente. $»^{11}$

En cuanto a la modalidad narrativa arborescente hecha de avances y retrocesos, fácilmente asociable a lo que acaba de ser dicho, un efecto digamos inmediato sería el de darle a la historia entera una dimensión onírica o imaginaria. La última frase del texto afirma que Nadia (la mujer anhelada) y su mundo « habían desaparecido para siempre porque yo había dejado de inventarlos » (207). Más allá de una " escritura a la vista » el procedimiento apunta a una poética que hace de lo narrado una construcción imaginaria explícita, lo que por supuesto se ve reforzado por la utilización de repertorios temáticos psicoanalíticos. Que los únicos libros que aparecen y son leídos con fruición sean libros violentamente obscenos no es, en este sentido, casual. El resultado de la variación sistemática es una curiosa representación de la ambigüedad -o, mejor, de la ambivalencia- de los deseos: a la vez violador y púdico, capaz de sadismo y de 
respetuosos gestos de solidaridad, excitado por el poder y sometido como un niño ante un pezón femenino húmedo de leche, el protagonista es un personaje, más que doble, múltiple, construido fundamentalmente a partir de conflictos con una fuerza pulsional incomprensible para él mismo, imposible de controlar, así como no se controlan los vaivenes de la narración.

Escribir una historia que no sólo avanza sino también retrocede, cambia de rumbo y sin embargo retoma, de alguna manera, las líneas abiertas en direcciones opuestas, es postular una narración que se opone al tiempo lineal, a la cronología ineluctable, a la versión unívoca. Desde ya, la multiplicidad de versiones o la proliferación discursiva como estrategias de representación de lo pulsional es un mecanismo del que hay muchos ejemplos, y por lo pronto el relato de otro uruguayo, Para una tumba sin nombre de Onetti. Este sistema supone una posición que rechaza los principios, si se entiende principios como, desde la denostada marquesa que sale a la cinco, aquello que, arbitrariamente elegido, cierra posibilidades y determina por su valor de restricción y de carga semántica lo que sigue. $\mathrm{O}$, mejor, un relato que trabaja con la fuerza y las promesas de los comienzos, sin confrontarse a las limitaciones, a las renuncias y a las inevitables decepciones que conllevan los desarrollos y los desenlaces : un relato que, para retomar el esquema narrativo de El lugar, funciona abriendo puertas, nuevas puertas que repiten y cambian al mismo tiempo lo que se venía diciendo.

Levrero se inscribe en una peculiar tradición de comienzos, una tradición incipiente pero reconocible, de un comenzar continuo. Desplazamientos, al borrar lo escrito y recomenzar la historias narrada, tiene algo en común, ante todo, con lo que lleva a cabo Italo Calvino en Si en una noche de invierno un viajero en 1979, o en todo caso con las fantasías del escritor ficticio que aparece en capítulo 8 de ese libro :

Quisiera escribir un libro que fuese sólo un íncipit, que mantuviese en toda su duración la potencialidad del inicio, la espera aún sin objeto. Pero ¿cómo podría estar construido, semejante libro? ¿Se interrumpiría después del primer párrafo? ¿Prolongaría indefinidamente los preliminares ? ${ }^{12}$

El relato de Levrero, al estar constantemente comenzando, abriendo puertas, imaginando posibilidades detrás de ellas, y retomando otros corredores sin necesidad de pasar por vías de acceso lógicas, encuentra una respuesta diferente aunque paralela a la de Calvino y a ese libro imposible, inimaginable. Desplazamientos es a la vez un relato y una ficción de creación, en sentido no sólo de un nivel clásicamente metadiscursivo, sino también el de una historia de escritura, cristalizada en los vaivenes de la intriga.

Una historia de escritura adjuntada o superpuesta a lo narrado. Al respecto, la crítica genética diría que hay que pensar el texto publicado por un escritor como un posible, un posible necesario que es el resultado de un proceso complejo, pero que podría haber sido otro. La « escritura a la vista » de Levrero en Desplazamientos expone todos los posibles, renunciando a la autoridad que implica elegir y fijar un texto definitivo ${ }^{13}$. En este caso, en el que lo regresivo y lo sexual dominan -en el que lo sexual como pasado y como pérdida domina-, los vaivenes narrativos crean un efecto de instalación en una situación en vez de una representación que comienza y termina. La variante inédita, como la fabricación de un nuevo dispositivo fantasmático, lleva conjuntamente a decir, fracasar, decir otra vez, delineando la censura y rehuyendo de ella al mismo tiempo. En una entrevista escrita a Pablo Rocca, Levrero expone su teoría del « suicidio perfecto » : «El suicidio perfecto, en cambio, te permite seguir viviendo y volver a probar. Consiste en matar a un yo que ya no te sirve, que te limita, te asfixia", aunque ese tipo de suicidio conlleve "pérdidas 
materiales importantes $»^{14}$. El comienzo perfecto que practica Levrero, parafraseando, permite seguir narrando, "volver a probar ", dejando de lado lo ya escrito, a su manera ya perdido. Este «volver a probar» expresa una fuerte carga pulsional, pero lo hace a través de una exacerbación de la forma (la que rige los comienzos de un relato y sus consecuencias), una forma convocada y transgredida a cada momento; la producción zigzaguea entre los códigos del comienzo y una apropiación personal que transgrede los principios esenciales de esos códigos.

Otra versión de lo mismo es ver las bifurcaciones del relato como una modalidad autoral del tachadura, o sea como un arrepentimiento en el que, tradicionalmente, la crítica genética lee una afirmación de intencionalidad, preferencia estética, elección cultural, todo lo cual hace del gesto a la vez un gesto de escritura y un gesto de (re)comienzo. $\mathrm{O}$, inclusive, una suspensión, dilación: algo insatisfactorio que queda por corregir, completar, rehacer ${ }^{15}$. Levrero, al retomar y reescribir, hace un uso sofisticado de un tachado imaginario, que es a la vez negativo (borrado), afirmación (doble enunciación) y representación de ese « tachado previo ». El tachado implica que hay algo que no llega a la escritura pero deja alguna marca, un esbozo. En esta perspectiva, y valga el exceso demostrativo, no es sorprendente que en uno de sus breves textos incluidos en Irrupciones , el número 8, Levrero escriba :

Encontré en el procesador de textos un botón que, al oprimirlo, permite ir tachando todo lo que se escribe. Lo interesante de este procedimiento es que permite ir tachando al mismo tiempo que se escribe. Me siento tentado de seguir escribiendo así, siempre. ${ }^{16}$

Se trata de escribir así para "siempre", tachar mientras se escribe gracias a un procedimiento (un botón), « seguir escribiendo » gracias a ello.

Desplazamientos : un relato no sólo plural, sino voluntariamente inacabado o inacabable, si se toma en cuenta la multiplicidad de caminos abiertos y no recorridos. Un inacabado que no es lo abierto o fragmentario, un inacabado que no apunta a una carencia, un vacío. Lo inacabado en tanto que lugar frontera, espacio relacional en donde el sentido queda por inventar. Un sentido dado tanto por lo escrito como por lo no dicho, lo que queda en blanco, lo que no se resuelve : todo empieza a suceder y nunca termina. Lo inacabado es lo que está surgiendo, lo inminente ${ }^{17}$. La exposición a la vez de los posibles del relato y del imaginario, el laberíntico recorrido de una escritura bifurcada, la ambivalencia que apunta al mismo tiempo a lo expuesto, a lo sugerido y a lo no dicho, todo esto señala una relación peculiar con el tiempo, el deseo y la escritura, relación que se focaliza y representa en ciertas elecciones formales. Una de ellas, entonces, es la de instalarse en un comienzo o en la posibilidad de retomar, a cada paso, un comienzo. Y así, alcanzar la «sombra », profundizar la « introspección » que, vimos, forman parte del proyecto de la novela.

Exposición de un comienzo como objeto del relato, ficción de creación de un libro imposible, afirmación de lo inacabado en términos estéticos alternativos, codificación de la escritura a la vista en tanto exploración del deseo, exacerbación formal de una percepción aguda del tiempo cronológico : estas constataciones, desarrolladas en párrafos precedentes, asocian Desplazamientos con otros libros de Levrero, aparentemente muy diferentes como Lugar. También podrían, si no me equivoco, aplicarse al tono, a la peculiar estructura y al singular pacto narrativo de La novela luminosa. 


\section{La pura puerta. La novela luminosa}

Que fuera imposible no era un motivo suficiente para no hacerlo, y eso yo lo sabía,

pero me daba pereza intentar lo imposible.

novela de la Eterna de Macedonio, otro libro póstumo, hecho de postergación de la escritura, otra novela inescribible que se desvía en prólogos, otro libro que se lanza hacia una quimera (la primera novela buena, aquí la novela luminosa), dejando de lado la literatura del pasado o la literatura posible (la novela mala, la novela oscura). Pero también, más significativamente todavía, la novela de Levrero nos remite a uno de los proyectos más desmedidos de la literatura en castellano, el que emprende el chileno Juan Emar cuando, en 1938 con una obra dispersa, atípica y poco conocida detrás suyo, se encierra, primero en el fundo La Marquesa y luego en una hacienda cerca de Temuco, con intermedios en Santiago y en una tienda de antigüedades en la Costa Azul, para escribir Umbral. Novela que dejó inconclusa con su muerte en 1964 y 5500 páginas más tarde. Novela imposible, Umbral está constituida por cuatro partes distintas, verdadera construcción material: Primer pilar, Segundo pilar, Tercer pilar, Dintel. Una extensión desmedida para un texto que representa, de manera paroxística, la obsesión levreriana por rondar alrededor de un comienzo, por encontrar una puerta, por montar un relato que sea una infinita promesa, la promesa sobre aquello que no se narra y que está, dijimos, detrás de la puerta.

¿Vale la pena continuar y evocar el final trunco de la obra de Flaubert, esa segunda parte inimaginable de Bouvard et Pécuchet que debía estar hecha de todo lo copiado por los protagonistas, o sea por una escritura mecánica, vacía, de la que sólo queda el sutil Diccionario de lugares comunes? Quizás no, aunque las analogías apunten a un fenómeno singular, el de esas obras que se cierran con un final abierto, que terminan en lo inacabado y en la ambición de otro comienzo. Pero estas simples coincidencias en tanto que circunstancias de escritura y de publicación, ponen de relieve tres contextos distintos para leer a Levrero : el suyo, ese final de una obra a principios del siglo XXI en América latina; el de las vanguardias históricas, en las cuales Macedonio y Emar se inscriben, hechas de experimentos, comienzos y crispaciones sobre el sentido; y por fin señalan la paradoja del final de una obra, la de Flaubert, que se sitúa en un principio ininterrumpido, final al que se le atribuye el acto de fundación de la novela moderna (o el acto de defunción del género, según cómo se mire). Novela del final, novela de comienzos, novela de postergación, novela de experimentación, son algunas coordenadas así visibles que enmarcan el sentido de La novela luminosa gracias al juego de paralelismos y semejanzas. 
38 En todo caso, y tomando un ejemplo más dócil, La novela luminosa, al igual que Paludes de Gide, ese diario de la exposición de la creación literaria, puede resumirse, con muchos bemoles, como la historia de la escritura de una novela ; o, si se quiere, un extenso libro sobre el comienzo de la escritura: una posposición del acto en sí, un puro comenzar, como en Calvino. En este caso no sólo no se va más allá del comienzo sino que se trata de una obsesiva reiteración de un comienzo frustrado : la historia, las peripecias, las causas de una no escritura. Retomando una recurrente observación de Barthes, diría que Levrero hace aquí del verbo escribir un verbo intransitivo (escribir a secas y no escribir « algo »), gesto que ya había desarrollado en El discurso vacío, y que tiende, por eso mismo, hacia un absoluto : escribir como "tendencia » diría el crítico francés, escribir como se fuma, función personal e íntima (es lo que le pasaba a Flaubert) ${ }^{18}$.

39 Tal cual se lo publica póstumamente en el 2005 con todas las marcas de la obra terminada (título, dedicatoria, aclaraciones, agradecimientos, fechas de redacción en prefacio y posfacio), el libro contiene, primero, un prólogo constituido por un diario que cubre intermitentemente un año de la vida del escritor ("Diario de una beca », de agosto del 2000 a agosto del 2001), año durante el cual éste intenta retomar la escritura de una novela dejada de lado muchos años antes (a mediados de los ochenta, época de escritura de Desplazamientos). Por el otro, los capítulos redactados, incluyendo un capítulo supuestamente suprimido y el capítulo que tenía que reemplazarlo.

El conjunto está enmarcado por una historia de la producción de ambos textos (prefacio y posfacio), que no sólo narra circunstancias, objetivos y fracasos, sino que además amplía lo publicado hacia, por lo menos, otros dos textos anteriores : el « Diario de un canalla » (1986, editado en 1992) y El discurso vacío (1989-1993, editado en 1996). Ambos "prototextos" presentan la forma de un diario y ambos ponen en escena la misma intención de una escritura imposible, interrumpida y constantemente comentada. En El discurso vacío, inclusive, la esterilidad del autor intenta ser resuelta con « ejercicios de escritura ", es decir supuestos ejercicios caligráficos, un " escribir bien », independiente del contenido de lo dicho (Sergio Chejfec supone que el «Diario de una beca », es una versión « exagerada y proliferante » de estos ejercicios) ${ }^{19}$. Y con respecto a « Diario de un canalla », ha podido considerárselo, a él y a todo el libro que lo incluye, El portero y el otro, como una bisagra esencial en la obra ${ }^{20}$. Por último, en la serie de textos afines habría que incluir el libro de colaboraciones a la revista Postdata, publicadas bajo el título « Irrupciones », el mismo utilizado para su edición reciente en libro. Aparecen entre 1996 y 2000, o sea que son inmediatamente anteriores al «Diario de una beca »; esas notas semanales en más de un sentido anuncian el «Diario». En particular, el uso de lo inmediato, la observación cotidiana, la puesta en ficción de la computadora, el ritmo puntuado por escrituras regulares, se asemejan. Y se asemejan, también, a una volátil serie de anotaciones de escritor, una libreta, que el tiempo ordena gracias a la decisión editorial de publicarlas en un volumen único.

41 Estos tres diarios sobre un proyecto inacabado e inacabable parten de una experiencia traumática, una operación quirúrgica que fue vivida, según el autor, como un paso por la muerte y como una mutilación, todo lo cual le impide retomar la escritura de esas experiencias positivas, a la vez espirituales, trascendentales y sexuales que, por ser «luminosas", compensarían lo turbio de la muerte y de ciertos fantasmas eróticos narrados en otros textos (en particular, en la denominada "novela obscura ", que en algunas declaraciones del autor es, como dijimos, Desplazamientos y en otras un manuscrito destruido). Vemos que en las justificaciones de Levrero se retoma la idea de 
una crisis, a la vez biográfica y metafísica, crisis que reorienta las características de una escritura; frente a la evidencia y la facilidad de los primeros textos, de la energía que los caracteriza, entramos en una situación nueva en que la dificultad (el «trancazo » dice Levrero, el « desperfecto » según Barthes, el « marinado » en la metáfora de Flaubert) ${ }^{21}$ es lo que se sitúa a la vez en el centro de la creación y en el horizonte de lo que se quiere interrogar e inclusive transmitir.

La descripción precedente resulta engañosa: de hecho, las abultadas páginas de esos diarios, aunque pretenden no tratar de nada, estar vacías como para dar lugar a la emergencia de una fuerza imaginaria que se desea recuperar, generan en los hechos un acercamiento inédito a la intimidad, estableciendo proliferantes y fugaces líneas argumentales, pero sobre todo dando cuenta de sensaciones, sueños, actos nimios, creencias mágicas, observaciones efímeras, ritos personales, sin ningún tipo de pose heroica o mitificante de una figura de autor y en una constante inmediatez entre experiencia y traza escrita. A partir de algo que se parece al quimérico objetivo de Flaubert (una novela sobre nada), se representa hasta el paroxismo a un yo disminuido, melancólico, hipocondríaco, verosímil y próximo, instalado en el umbral de una experiencia modestamente mística (en El discurso vacío : « Recuperar contacto con el ser íntimo, con el ser que participa de algún modo secreto de la chispa divina que recorre infatigablemente el Universo y lo anima, lo sostiene, le presta realidad bajo su aspecto de cáscara vacía $»)^{22}$. No es sorprendente, después de lo dicho, que la escritura quimérica de esta experiencia dialogue subterráneamente con los valores míticos del origen.

Simétricamente, los capítulos de la frustrada novela "luminosa», no presentan características radicalmente diferentes a las del prólogo : no hay otra diégesis, sino una continuación de interrogantes sobre, ante todo, las razones de la novela proyectada. Se narran las circunstancias que harían posible la escritura de esa novela utópica, postergando y explicando el verdadero inicio, es decir se justifican los motivos, los objetivos y desencadenantes, sin que se cumpla, obviamente, lo deseado. El fantasma de escritura se hace trizas contra las posibilidades reales del que escribe ; el libro soñado es el que podría escribir otro, no ese yo a la vez destrozado y omnipresente, interrogado y representado hasta el hastío, hasta las últimas consecuencias de la impotencia (el otro no existe, el otro no soy yo), dentro de una lógica de la diseminación del sujeto ${ }^{23}$. Porque si tomamos al pie de la letra sus afirmaciones, Levrero no sólo no logra continuar la escritura de estos primeros capítulos, sino que lo ya redactado no se corresponde, de ninguna manera, con lo planeado: la trascendencia espiritual y sexual que se quiere transmitir no está presente en estos textos, de nuevo dudosos y zigzagueantes. $\mathrm{O}$ sea, y tomando el ejemplo de Proust leído por Barthes, la novela luminosa no « cuaja » nunca, permanece en un estado de proyecto, de dispersión, de acumulación heterogénea ${ }^{24}$. Estamos ante un libro inescribible que, a diferencia de los libros ideales de Borges (la Enciclopedia de Tlön, el Libro de arena, El jardín de los senderos que se bifurcan), sí se intentó, alguna vez, llegar a crear (es lo que hizo Joyce en Finengan's wake, una proyección más allá de lo pensable, o lo que intentó Mallarmé con su extraordinario Libro).

En todo esto, varios niveles apuntan a un contenido asociable con lo genético, tanto en términos de documentos como de relatos e informaciones, aunque sea, digamos, un contenido que cabe denominar una "ficción genética ». Evidentemente, puede leerse la novela a partir de la práctica insólita del género diario o de los paroxismos melancólicos que deja entrever el discurso del narrador; aquí, sin desdeñar esos aspectos, vamos a concentrarnos en la percepción del texto como una prolongación de gestos formales e 
imaginarios de escritura ya analizados, todos asociables en alguna medida con el amplio espectro de la " preparación a la novela » y de una repetida teorización sobre las libretas de escritores, lo inacabado, los borradores, los relatos de escritura y, evidentemente, los gestos de comienzo. Anne Herschberg-Pierrot asocia los modos de producción y el resultado, viendo en los principales rasgos de la génesis una modalidad de estilo, hecho de convergencias, tensiones y repeticiones, y que podrían percibirse tanto en la producción como en el resultado publicado. También comenta otras características operativas en la génesis : la heterogeneidad y lo inacabado. Lo inacabado, en particular, merece ser declinado en características distintas según ella, como el manuscrito interrumpido, el manuscrito abandonado o el manuscrito preparatorio. Lo inacabado difiere pero resuena, también, en lo fragmentario ${ }^{25}$. Es un modus operandi confesado por Levrero :

Eso es : el sentimiento que predomina es el de incompletud. Si pudiera reunir toda la información, si pudiera armar toda la historia, perdería interés de inmediato, y por supuesto, me olvidaría de esa historia -porque lo que cuenta para mí es el descubrimiento, el ir armando el rompecabezas-. (248) ${ }^{26}$

En términos de relato de comienzos figuran, ante todo, las razones de la escritura. De manera tradicional leemos un comentario sistemático sobre el sentido del proyecto, la intencionalidad, los objetivos, los valores, la carga imaginaria de esa voluntad de creación, en particular una serie repetitiva y contradictoria de afirmaciones sobre la motivación de la obra. Es una presencia tenue pero constante ( En algún momento de estos días pensé que estaba mezclando el diario con el proyecto y no estoy seguro de que estas páginas no correspondieran más bien a la novela luminosa »), siempre frustrada ( « no [hay] aquella magia luminosa que he buscado, y busco, registrar en la novela, sin éxito visible ») (376-377). El proyecto obedece a una serie de experiencias y solicitaciones confusas: desde una respuesta a preguntas de la hija a la afirmación de una espiritualidad, a la evocación de percepciones y de vivencias, en particular eróticas, que se contraponen a la enfermedad y a la depresión, e incluso a la narración de anécdotas sexuales imaginarias (una polución nocturna después de un sueño sexual con una mujer fea por ejemplo). Este horizonte de superación de lo material y lo mortal estaba presente, como vimos, en la obra anterior e introduce una idea de la trascendencia, en donde elementos cristianos, elementos de parapsicología y espiritismo, se combinan con cierto solipsismo y con lecturas freudianas. La novela luminosa se sitúa, como antes Museo de la novela de la Eterna y Rayuela, en el cruce de la pregunta del sentido y de la espiritualidad, postulando una confusa metafísica, lo que no es del todo ajeno al paroxismo del comienzo (quiero decir: el comienzo, el umbral, es un paroxismo interrogativo). Y, valga el paralelo, los tres textos incluyen en esa dimensión el tema de la pérdida amorosa y el de un objeto de deseo huidizo.

A este complejo mapa de razones, motivaciones y afectos puestos en la escritura se le agrega, como corresponde, una historia de la escritura. En varios momentos del texto (" Prefacio », « Diario », "Capítulos », « Epílogo ») se incluyen fragmentos de un relato de estos intentos, es decir que el escritor propone una reconstitución narrativa del proceso. Así, nos enteramos que los capítulos incluidos fueron escritos en 1984, salvo uno, del 99, que debía prolongar la novela y que finalmente se integra aparte, fuera de la numeración (es el único que lleva un título, "Primera comunión »); o que un capítulo, considerado " sensiblero ", había sido destruido en su momento y fue reescrito ; sin embargo, el autor " encuentra " una copia y lo incluye (la novela contiene dos estadios de escritura, dos borradores distintos entre los cuales el escritor no elige : un capítulo « tercero-cuarto » y otro « cuarto-quinto ») (16). A la historia se la completa entonces con una inclusión de los 
textos comentados, con la presencia de versiones diferentes del mismo texto y con glosas profusas sobre lo que se desea escribir (o sea, materiales prerredaccionales y borradores), $\mathrm{y}$ alusiones a otros textos (los que llamamos protoversiones).

La novela luminosa es un caso extraño, el de un libro que, a pesar de su sistema paratextual habitual y aparentemente terminado, es un borrador trunco y un comentario por parte del escritor de las condiciones de una supuesta no escritura. El « dossier genético » de la novela forma parte del libro y se escribe en parte después del texto definitivo, esos capítulos ya terminados. Es extraordinaria, como puede verse, la coincidencia entre este libro y el auge de la crítica sobre borradores y la exaltación de los manuscritos, como lugar legendario de la palabra literaria. En particular, nótense las ambivalencias sobre la destrucción de manuscritos; se destruye la novela oscura pero en otros textos se afirma que es Desplazamientos; se afirma haber destruido el capítulo tres, razón por la cual el capítulo siguiente resume y retoma parte de su contenido, pero al mismo tiempo se lo incluye, como si un hada providencial hubiese protegido al escritor permitiéndole proponer dos versiones del mismo texto. En todo esto, el autor/narrador aparece desprovisto, no sólo de memoria, sino de autoridad. Expone los hechos y los documentos que se acumulan y ordenan a pesar suyo. Un vacío de voluntad, simétrico al vacío del discurso, que acrecienta la impresión de un dossier escrito por otro y ante el cual Levrero no tiene más recuerdos ni posibilidades de conocimiento que cualquier ajeno. La concepción de una identidad de autor diferente y autónoma del sujeto biográfico, varias veces expuesta por Levrero, se corresponde con este desdoblamiento y este vaciamiento.

La despersonalización y la exposición de la escritura en términos dubitativos y de procedimiento, se parecen a gestos que, Ponge en poesía y Perec en novelas, ya habían intentado ; asimismo, Boie y Ferrer comentan el caso de Doris Lessing, que falsificó un dossier genético imaginario y publicó un diario íntimo inventado bajo una falsa identidad (El diario de Jane Somers) ${ }^{27}$. No estamos ante la consabida "aventura de una escritura " incluida en el argumento, sino la escritura a partir de lo que sería una versión ficticia de un dossier genético. En ese sentido, el libro utiliza y hace funcionar una dimensión intertextual insólita, la que caracteriza la relación entre un texto terminado y los borradores y documentos preparatorios que, habitualmente, la crítica genética estudia.

Una narración meticulosa del proceso de escritura, pero también, en el «Diario de una beca " una serie importante de comentarios materiales sobre cómo se escribe, a partir de qué ritos e inspiraciones, cuáles son los obstáculos y cuáles los procedimientos para intentar avanzar. Vale decir sobre las herramientas del proceso (papel, lapiceras, caligrafía computadora), como los actos (escritura, lectura, impresión, relectura) y las formas (el imperativo del género diario, las lecturas de otros autores, etc.). Así se suceden informaciones múltiples al respecto : relación con el papel y la caligrafía ("pésima calidad de mi letra actual, después de años de no ejercitarme », lo que alude a $\mathrm{El}$ discurso vacío) (118), disquisiciones sobre lapiceras (« está todavía la lapicera Staedtler con la que escribí la 'novela luminosa' ») (163), alternancia de escritura informática con escritura a mano, ritmo de redacción, modalidades de las correcciones y efectos de la relectura («mal escrito y todo, me parece una lectura interesante ») (148), lectura de ciertos textos inspiradores (como un diario de Rosa Chacel o Las Estaciones -Las moradas- de Santa Teresa de la Cruz), y tipo de programaciones de la computadora (por ejemplo, programación de una macro de Word para ordenar automáticamente lo ya escrito, o invención de una opción para fechar, también automáticamente, cada fragmento, o creación de una identidad diferente de usuario de la máquina si se trata de «escritor» o del otro, el 
hombre que pasa su tiempo jugando con juegos informáticos o coleccionando fotos y videos pornográficos).

De todo esto, un elemento central es el vínculo que se establece con la computadora. La escritura o la no escritura es en parte narrada de manera indirecta, desviada, en la relación que se establece con la máquina, espejo deformante. Sin detenernos en ejemplos de una línea temática omnipresente, se puede afirmar que la computadora cumple varias funciones diferentes, que tienen todas que ver con una forma de sustitución: de la escritura, de la sexualidad, del objeto perdido, del sujeto Levrero. Es un espacio vacío, que materializa el agujero o la nada de la depresión, una especie de forma hueca, protectora al mismo tiempo del abismo negro de la melancolía; es un reflector de pulsiones contradictorias confusas, un lugar de adicción, comparado a veces con las drogas (el autor usa el término "desintoxicación» al respecto detallando sus vanos esfuerzos por desprenderse de ella), e inclusive es un ser que, como el propio cuerpo, se enferma, tiene virus, reacciona, estalla.

51 Más allá, la escritura se lleva a cabo contra y partir del código de la computadora, y no solamente del género diario. Computadora, máquina de escribir, lugar de creación o de emergencia, pero máquina de escribir o facilitadora de escritura con un reloj incorporado, una forma de inteligencia, que se estructura con algo que se parece al azar, que responde con una sorprendente capacidad de jugar con probabilidades y que puede además ofrecer exóticas japonesas desnudas o mujeres con abundantes pechos. El de Levrero es un intento de plasmar la locura o la melancolía, como tantos otros antes que él, pero también el de introducir al código de la computadora en el imaginario de la creación, en substituto de la página en blanco, la escritura automática y otros mitemas de la escritura. O sea, ocupar con el imaginario una técnica reciente, humanizando lo inhumano de la modernidad, integrando lo nuevo en la literatura. Lo que es una manera inédita de pensar y de representar el comienzo del texto.

52 Al respecto Levrero ya escribía, en El discurso vacío, que la computadora viene a «sustituir» lo que un tiempo fue su «inconsciente como campo de investigación ${ }^{28}$. Pero, por otro lado, en la computadora se integra una instancia normativa que organiza el tiempo y la escritura (hay programas para indicar toma de medicamentos o consumo de conexión internet) y, como dijimos, propone posibilidades de organización y de construcción : programas corregidos, como un texto, o inclusive inventados, como una ficción. Todo lo cual, por supuesto, gira alrededor del vacío, del código impenetrable de la informática (algo así como la Ley en Kafka o el Orden en la Biblioteca de Babel de Borges); desde muchos puntos de vista distintos, la computadora funciona como una metáfora o espacio proyectivo, sustitutivo de la psiquis del sujeto, en particular del sujeto-escritor. Es la apoteosis de una despersonalización, pérdida de sentido, organización absurda de puro código, inherentes al sujeto melancólico.

53 Este obsesivo conjunto de informaciones sobre la escena de escritura incluye toda una teoría, o digamos una praxis, sobre el origen de la literatura, que en coherencia con los relatos anteriores de Levrero y abundantes declaraciones suyas tiene que ver con modos de introspección. No se escribe lo proyectado pero se transcriben interrogativamente sueños, se especula con el proceso de recuperación de recuerdos, se observa la emergencia fugaz del deseo o la existencia de premoniciones. Se busca, como en una práctica espiritual, el ocio, el vacío, la disponibilidad, en espera de una señal, volviendo una y otra vez sobre el miedo a la muerte. Se transmiten insólitas fantasías anatómicas (la barba le da la impresión, al tocarla, de estar acariciando un pubis femenino « pero que ese 
pubis esté en mi mentón hace que este tic sea bastante sospechoso ») (56). Se acumulan fobias, miedos, contradicciones; e inclusive, confesión de resistencias ( Parece que el inconsciente se resiste a ser expuesto de esa manera y no tengo por qué ejercer violencia contra mí mismo ») (146-147). Con un notable y modesto exhibicionismo, se expone al hombre que escribe, en vez de poner en escena a un personaje de autor; en este sentido, el objetivo es el buceo en trasfondos impúdicos del sujeto. La escritura es una experiencia en todos los sentidos, una vivencia material e imaginaria al mismo tiempo, ampliamente presente con ese cariz en esas páginas.

Junto con ese origen de la creación, legendario a su manera, la escritura de lo cotidiano da lugar, en La novela luminosa, a una representación fuerte de lo que todo especialista en manuscritos querría conocer, sabiendo de antemano que está fuera de su alcance : la vida cotidiana, los estados de ánimo, las asociaciones y sueños, las experiencias e incidencias materiales, los ritos, la intimidad (inclusive fantasmática y sexual como vimos) del momento de la escritura. La reconstrucción genética es un asunto de probabilidades, de conjeturas, no de certezas ${ }^{29}$; pero en el caso de Levrero nos acercamos a lo más inmediato del pensamiento, del imaginario y de las acciones del escritor, o a una ficción verosímil sobre el tema. Desde las disquisiciones sobre la calidad del yogur, causa de malestares gastrointestinales como asimismo la del pan o del aceite (aceite que, para ser digerible, tiene que ser importado), a contenidos de nimias llamadas telefónicas, todo se anota, en particular los actos inmediatos que acompañan la escritura, como en este ejemplo de lo « instantáneo »:

Se llamaba...

fui a buscar un cigarrillo. Noventa minutos sin fumar ; bien. Pero estuve jugando Gold. Sísifo. Se llamaba Sísifo. Me acordé mientras iba a buscar el cigarrillo. (40)

Así se pone respectivamente en escena el proceso del recuerdo y el recurso irónico a la expectativa narrativa folletinesca (irrisoria : "Ahora voy a comer. Continuará.») (83), pero ante todo se inscribe en el primer plano del texto una coordenada mayor, que es la escritura en función y en tensión con el tiempo. El género diario estructura al texto con fechas y horas, obsesivamente anotadas, aunque se dude de su pertinencia (« Yo no sé si algún lector se interesa por la indicación de fecha y hora que titula cada capitulito de este diario; cuando yo leo diarios ajenos, por lo general es como si esas indicaciones no existieran », "Escribir diariamente sobre los sucesos frescos es un error ») (62 y 323). Y no sólo un diario, con su acompasado ritmo de fechas y su recapitulación de los principales acontecimientos de las últimas horas, sino también una libreta de anotaciones, según su uso tradicional, en donde se captura el instante y la ocurrencia o percepción fugaces, y que resulta, luego, un observatorio eventual de la vida del autor ${ }^{30}$.

Es decir, la escritura inmediata, la escritura sobre nada, pero también la escritura fechada, con un doble procedimiento. Por un lado, la « escritura del día », es una manera de contraponer a la imposibilidad un gesto de creación y a la exposición de lo escrito, la escena de escritura. La inmediatez, el ahora, el gesto en sí que marca la hoja o la pantalla con la palabra que aparece en el momento de lectura, son elementos que cristalizan una visión del presente como única realidad palpable. 0 una utopía de que el ahora de lo que se está escribiendo sea a su manera eterno, que el tiempo del escritor sea siempre éste. Exaltación del instante que lleva a señalar obsesivamente las cuestiones de horarios ( A cada rato son las seis de la mañana » escribe un Levrero que duerme de día y no logra readaptarse a los horarios habituales de la vida cotidiana). Tiempo subjetivo, tiempo de la computadora, tiempo de un interior diferente del tiempo social : el « Diario de una beca » 
hace de la creación literaria un terreno de otro tiempo, una construcción de un tiempo distinto, a la vez fugaz y eterno.

Pero, de la mano del género diario, las marcas temporales que puntúan el texto funcionan también, otro procedimiento, como un código, un soporte, una estructura para una escritura posible. Ejemplo extremado, en una entrada entera se numeran los actos realizados durante el día, como si crispándose en la sucesión ordenada de acontecimientos se pudiera superar la parálisis de escritura, desde "1) Me levanté a una hora casi razonable » a « 35) Voy a comer un par de galletas y tomar un café y me voy a acostar » (179-185). Fechar es ordenar y representar algo de lo que se sabe perdido, sea cual fuere su interés, forma general o trascendencia. Más allá de la angustia por la muerte, la hipocondría, la presencia del pasado y de la pérdida en el texto, o sea más allá de una repetida tonalidad melancólica, el tiempo es a la vez la materia de lo que se escribe y un predicado obsesivo.

58 Las reflexiones sobre el tema son frecuentes. Por ejemplo, en el capítulo Tercero-Cuarto, después de una imagen alegórica de la vida como un viaje en un « enorme ómnibus » que avanza a toda velocidad en medio de la nada hacia un destino desconocido y en compañía de una muchedumbre hostil, el narrador expone su teoría del tiempo hecho de trenes: "[...] según esta teoría, uno viene tomando trenes que van hacia distintos destinos y marchan a diferentes velocidades -y toma varios de estos trenes al mismo tiempo, incluso algunos que viajan en sentidos exactamente opuestos » (503-504) Frente a la proliferación de tiempos (heterocronía del mundo, y en particular la del manuscrito, en donde se cruzan y superponen tiempos dispersivos), se entiende el uso de los mojones propuestos por el género diario : el orden y la fecha implican un intento de tomar el toro por las astas $\mathrm{y}$ ordenar el proceso. $\mathrm{O}$, en todo caso, se pone en escena un contrapunto entre el tiempo cronológico y la explosión de tiempos subjetivos que permiten, al alargarse indefinidamente y situarse fuera de lo medido, significar una posición digamos existencial, más allá de lo dicho explícitamente. Todo lo cual tiene que ver con el proyecto de La novela luminosa :

Pues debo insistir en el hecho de que ninguna de las experiencias luminosas y ninguna de las experiencias liberadoras ha servido para poder decir « ya está », « ya llegué », « era esto ». Por otra parte, si alguna vez busqué -y vaya si lo he hechoalcanzar algo que me permitiera decir "ya está », "ya llegué », ahora soy muy consciente de que eso sólo se alcanza con la muerte.» (478)

Otro ejemplo, anterior, en "Apuntes bonaerenses", de una superposición entre imaginarios temporales y la emergencia de la literatura, en términos paradójicos :

[...] el tiempo es una masa cálida girando en torno a sí misma, conteniéndolo todo, sin soltar nada ; un tiempo de dispersión, pero también de conservación de los hilos dispersos. Nada se pierde, pero nada deviene ; nada puede nacer, lo que aparenta nacer, ya era, una y otra vez, cada acto, cada gesto, cada cosa, todo tiene el sabor de lo ya vivido muchas veces ${ }^{31}$.

60 Lo múltiple (lo « disperso ») es a su manera inmóvil y rechaza la cronología, lo ineluctable de la pérdida, pero también descree de la creación («nada puede nacer »). A pesar del ritmo de los días que el género diario acentúa, el escritor permanece en ese girar sobre sí mismo, sin « soltar nada ». Un ideal y una pesadilla presentistas.

61 En este sentido, el uso que Levrero hace del género diario es diferente del habitual (y retomo en lo que sigue afirmaciones de Ana Inés Larre Borges) : no se trata de « vivir para anotar lo vivido », ni de " escribir para vivir » ni de creer, como Katherine Mansfield, que en el diario está la verdadera vida. No es el lugar de experiencia en sí, no es un texto con 
un destinatario secreto, ausente, no es una escritura íntima y no corregible, no es una escritura paralela a la de la obra (como Gide publicando Los monederos falsos en 1925 y Diario de Los monederos falsos al año siguiente) ${ }^{32}$. El paroxismo de inmediatez, dispersión y orden cronológico son, en Levrero, un reemplazo del relato, una manifestación de lo que se juega en las bambalinas de la escritura. Tampoco es un texto espontáneo que actualiza el mito de la sinceridad frente al artificio de la creación, sino un experimento narrativo, un laboratorio, una manera de prolongar, en otros terrenos y con otros postulados, lo escrito antes. El comienzo es una forma de escritura, no una reflexión sobre lo que se escribió o lo que se escribirá ; el intento de plasmar el instante, la cadencia de fechas, los tanteos ante el umbral de lo ideal : ése es el proyecto, tal cual se lo percibe al terminar la lectura.

Por último, de más está decir que no hay historia sin un comienzo. Ya en El discurso vacío, Levrero hacía de un "reaprendizaje » de la caligrafía el ejercicio, a la vez irónico y simbólico, del escribir bien. Y prolongando lo dicho, notemos que el «Diario de una beca » es nada menos que el diario del año 2000, comienzo de milenio, confirmando así la trascendencia de la cronología ( « El primer día del milenio levanté la persiana en algún momento y vi que junto la cabeza de la paloma muerta... ») (294). El milenio es una frontera cruzada con el diario, observando una especie de actualización urbana de las Vanidades, lo que se repite en las últimas líneas del « Epílogo del diario » : «La calavera de la paloma parece seguir en su sitio... » (565).

63 El principio se confunde con las motivaciones de escritura y es por lo tanto plural. Por lo menos cuatro imágenes distintas figuran como disparadores de escritura, inclusive, en uno de los casos, la de una experiencia que se promete narrar y no se narra. El dispositivo lleva, por otro lado, a multiplicar los comienzos : comienzo del « Prefacio », comienzo del primer texto del primer día del diario de la beca, comienzo autoimpuesto el $1^{\circ}$ de diciembre, ampliamente comentado pero que no tiene lugar, comienzo del texto después del Año Nuevo, comienzo del primer capítulo de la novela, lista no exhaustiva a la que habría que agregarle los comienzos de «Diario de un canalla y de El discurso vacío, íncipits significativos para la comprensión de esta novela. Así da cuenta del intento de aplicar ese « nuevo comienzo » del diciembre del 2000 :

Martes 5, 00.02:

Ayer de madrugada comencé. O mejor sería decir "continué ", porque resolví aprovechar lo poco que había escrito en enero. Viene sucediendo desde hace tiempo que en el momento de irme a acostar, desarrollo mentalmente el texto, o las imágenes, o el clima, de lo que quiero narrar; a menudo lo voy poniendo, mentalmente, en palabras. Ayer de madrugada estaba perfilando una vez más la continuación de la historia que había comenzado a narrar en enero, cuando vi claramente que me estaba repitiendo y que invariablemente todo eso caía en el vacío ; siempre pensaba " mañana voy a escribirlo », como quien piensa en empezar un régimen para adelgazar o un plan para dejar el cigarrillo. Pero hoy me dije «Mañana no existe, no existirá nunca. El proyecto no se moverá. Esto que estoy pensando lo debo escribir ya, porque cuando mañana me despierte voy a enredarme con las mil cosas con que me enredo cada día y el texto se irá postergando hasta la hora de irme a dormir y... (243)

64 Esta intención de comienzo es dos veces metanarrativa: por un lado, una especie de autoinstrucción como las que abundan en las anotaciones privadas de escritores; por el otro, un resumen y explicación cifrados del « Diario de la beca » (escribir lo que existe, es decir, ese enredarse en mil cosas cada día, lo que ocupa el lugar del texto postergado e imposible). 


\section{Una puerta intransitiva} comienzo, la escritura sistemática que posterga el trabajo que se intenta realizar, la profusión de preámbulos, explicaciones liminares y anuncios, todo lo cual permite concluir que, en este caso, el comienzo es, digamos, imperfectivo : la intención es la de no dejar de comenzar. Es un comienzo intransitivo, hipertrofiado. Levrero transforma, a cada paso, el gesto de continuar en un comienzo : no dejar de empezar a continuar, es decir que todo el provecho de haber comenzado y todas las ventajas de lo ya escrito se anulan en una repetición sin fin de la página en blanco, aunque se acumulen tantas ya redactadas. No terminar, ni continuar, ni siquiera cuando se retoma una novela empezada quince años antes, sino seguir empezando, como para descartar del escritorio el fantasma de la muerte. espacio más allá de lo posible en el que se condensan deseos y perfecciones, « rectángulo imaginario ", metáfora para referirse al proceso de creación, hecho de proyecciones que dominan en la mesa de trabajo, escritura fuera de alcance que justifica y motiva la desaliñada y decepcionante escritura que sí se puede seguir llevando a cabo ${ }^{33}$. Frente al texto real se esboza la presencia de otro texto, y ese otro texto es la justificación, por contraste, del que leemos. Es un «fantasma de escritura », expresión que debe tomarse, afirma Barthes, con toda la fuerza deseante, es decir la de un yo produciendo una posesión imaginaria de un objeto deseado y siguiendo la definición psicoanalítica del fantasma (« guión imaginario en el cual el sujeto está presente y que figura la realización de un deseo $)^{34}$. En este caso sería el fantasma, no de un contenido, sino el de una superficie, una forma, una obra por hacerse. Seguir comenzando o no poder terminar los capítulos ya escritos mantiene viva a la otra escritura, materializada en ese movimiento de constante intento y fracaso.

67 Ahora bien, lo inacabado de lo que se trata no es obligatoriamente lo no terminado; también puede ser una expectativa, un paso, una encrucijada en la que, siempre, algo puede producirse. No una encrucijada en el sentido de la narratología, duda entre posibles del texto que se compone, sino en el de múltiples imaginarios de la obra, entre el imaginario ya escrito y los imaginarios posibles de las vivencias del sujeto, entre lo que el sujeto fue o lo que es y lo que será, sabiéndolo o no. Lo inacabado es un lugar frontera, espacio relacional, signo de un sentido por inventarse ; es un signo diferente : lo blanco, lo no dicho, la escritura desordenada, sin fin, apuntan a lo posible y a lo imposible al mismo tiempo ${ }^{35}$. O La novela luminosa no es una novela inacabada, sino escrita "para después », salvo que ese « después » no está incluido en ningún calendario futuro ${ }^{36}$.

68 Este comienzo imperecedero en tanto que lugar de escritura materializa, por un lado, los ideales presentistas contemporáneos, pero también es una radicalización de ciertas constantes de la escritura moderna, es decir la tradición de la gran novela, siempre en tensión entre la forma, el cierre perfectos y el salto hacia otros terrenos de escritura. En ese sentido, Levrero acentúa un aspecto poco comentado, presente en grandes nombres como el de Stendhal o el de Flaubert. Por ejemplo, Jacques Neefs afirma que ambos escritores trabajan en alguna medida con lo no terminado, con los huecos o la desviación. Citando a Genette, Neefs recuerda que en Stendhal, el vacío, la interrupción, no es un ausencia, un no texto: es una carencia activa y sensible en tanto que carencia, es el 
espacio de lo inescrito, es un texto inescrito ${ }^{37}$. Por su lado, Jean-Marc De Biasi cita a Flaubert calificando de « inepcia » el « querer concluir » y agrega : « Flaubert no dejará de insistir sobre la exigencia de lo no concluido, sobre la necesidad de restituir en la forma el dinamismo ininterrumpido que caracteriza el devenir histórico, manteniendo en la obra un espacio de vacuidad, de inacabamiento, y de indefinición sin el cual no podría considerarse lograda en tanto que obra». ${ }^{38} \mathrm{El}$ comienzo puede convertirse en el objetivo mismo de la creación ${ }^{39}$.

Un movimiento que permanece entonces, no dejamos de constatarlo, en los umbrales. La escritura siempre queda para después, para un momento en que sí se podrá juzgar y evaluar la obra, entonces «terminada ». Esperando ese horizonte quimérico, se trata, no de escribir sino de estar escribiendo, de mostrar la acción que en un vaivén constante instaura un objeto y constata su pérdida, indefinidamente. 0 , si repetimos la metáfora de un rectángulo imaginario, la forma fantasmeada del libro es, aquí, una infinita página en blanco. De una manera insólita, la resistencia de los códigos novelescos, los imperativos de tener un comienzo y un final, verdadera aporía formal para Levrero, son productores de literatura : la imposibilidad de ir más allá es lo que permite el surgimiento de este libro extraño que apunta a direcciones imprevisibles.

Para terminar, una concesión a los mitos de la determinación del comienzo y otra al «demonio de la analogía ». Analogía: Kafka, en su Diario, comenta ampliamente su « incapacidad de escribir ». Y aunque no pueda acceder a las causas, en un momento dado cree comprender esa incapacidad. Es la de no encontrar un comienzo, ya que siempre imagina a lo escribible como ya iniciado :

De hecho, todas las cosas que se me ocurren, no se me ocurren desde su raíz, sino sólo desde algún punto situado en su mitad. Que intente entonces alguien agarrarlas, que alguien intente coger una hierba y retenerla junto a sí, cuando esta hierba sólo crece desde la mitad del tallo para arriba ${ }^{40}$.

71 Este otro escritor de lo inescribible busca el punto de partida que le permita «asir » el relato, y por lo tanto escribirlo, tanto materialmente como semánticamente. Un no escribir asociado a un mundo sin fin y sin principio, sin marco; un relato sin raíces y sin flores, que nadie puede «retener junto a sí ». Y, singularmente, la imposibilidad de escribir será, en Kafka, la de no lograr terminar lo comenzado : los inicios que encontrará no permitirán grabar en una Obra su hierba volátil. Ejemplo opuesto y simétrico al de Levrero, que establece un vínculo menos visible que otros entre ambos escritores.

Del lado de la determinación inaugural, no es superfluo recordar que el continuo comienzo del « Diario de una beca », a pesar de la presentación hecha más arriba, tiene su propia génesis en la obra de Levrero, génesis que gira alrededor de una práctica asidua algo así como una puesta a punto-, del género diario. A partir de los diarios incluidos en El portero y el otro, se escribe, una y otra vez, lo que aparece progresivamente como una modelización del diario en tanto que alternativa a la escritura de relatos, lo que va a prolongarse con el diario de un recuerdo, Burdeos, 1972. Uno de ellos, simultáneo a « Diario de un canalla ", trata, fundamentalmente, de vagas fantasías amorosas junto con momentos de observación, momentos aparentemente vacíos. El texto, ya citado, se intitula « Apuntes bonaerenses » y su íncipit parece resumir lo dicho sobre este aspecto :

3.I.86 Abrí la puerta. No ; no exactamente. Quiero decir : allí estaba la puerta, yo estaba delante de la puerta. Yo estaba de este lado, la puerta estaba allí ; estaba cerrada, y entonces abrí la puerta. Pero no quiero decir que estuviera cerrada con llave; yo no tenía la llave. Tampoco tenía que accionar el picaporte, porque en realidad no estaba cerrada, no estaba del todo cerrada. No es que haya abierto la 
puerta, pero la puerta estaba allí ; yo la empujé, y giró sobre sus goznes. No lo suficiente, de primera intención; para pasar el cuerpo por allí debía empujar nuevamente, un poco más. Pero no lo hice ; ni pasé el cuerpo por allí. Abrí la puerta, y me quedé allí, esperando ${ }^{41}$. pero bastante como para haber producido un cambio, ésa es la posición de escritura de Levrero ; es la de la espera, la espera de nada, la espera porque, después del primer acto, la apertura se detiene. Esa vacuidad, ese tiempo que no comienza sino que continúa y gira en sus textos, ese no tiempo por lo tanto delante de una puerta que uno mismo ha abierto y que no se puede atravesar : en todo esto hay algo del personaje esperando toda su vida ante las puertas de la ley en Kafka, como dijimos al inicio de este capítulo, o una recuperación invertida del procedimiento narrativo de El lugar.

Abrir, puerta, paso, metáforas tradicionales del comienzo de escritura que aquí logran la paradoja de detener el movimiento a pesar de que la escritura continúa. Ser escritor es estar escribiendo, o sea, estar comenzando. No es haber escrito y no es una esencia : ser es hacer y hacer es no hacer, es escribir que no se escribe, para poder, todavía, soñar que se escribe todo.

\section{NOTAS}

1. Hugo Verani, «Mario Levrero : aperturas sobre el extrañamiento » en Ezequiel De Rosso, La máquina de pensar en Mario. Ensayos sobre la obra de Levrero, Buenos Aires : Eterna Cadencia, 2013, p. 39-60.

2. Mario Levrero, El lugar, Barcelona : Debolsillo, 2009. Para todos los libros de Levrero citados, los números entre paréntesis remiten a las páginas de las ediciones trabajadas.

3. Sigmund Freud, El malestar en la cultura. Obras completas tomo 3, Madrid: Biblioteca Nueva, 1996, p. 3018.

4. Mario Levrero, "Gelatina », en La máquina de pensar en Gladys, Montevideo : Irrupciones, 2011, p. 83.

5. Mario Levrero, La ciudad, Barcelona : Debolsillo, 2009, p. 21.

6. Martín Kohan, « La idea misma de ciudad », en Ezequiel De Rosso, op. cit., p. 109.

7. Louis Hay, «L'écriture vive » en AAVV, Les manuscrits des écrivains, París : Hachette/CNRS, 1993, p. 23.

8. Jean Laplanche y Jean-Bertrand Pontalis, Diccionario de psicoanálisis, Barcelona : Paidós Ibérica, 1996, p. 98.

9. Este es el epígrafe : «'A todo individuo le sigue una sombra (...) Si las tendencias reprimidas de la sombra no fueran más que malas, no habría problema alguno. Pero, de ordinario, la sombra es tan sólo mezquina, inadecuada y molesta, y no absolutamente mala.' Carl Gustav Jung, Psicología y Religión (111)».

10. Mario Levrero, Fauna. Desplazamientos, Buenos Aires : Ediciones de la Flor, 1987

11. Pablo Silva Olazábal, Conversaciones con Mario Levrero, Buenos Aires : Conejos, 2013, p. 93.

12. Italo Calvino, Si en una noche de invierno, Madrid: Siruela, 2014, p. 153.

13. Paul Ricoeur, « Regards sur l'écriture » en Louis Hay, La naissance du texte, París : Corti, 1989, p. 217. 
14. Pablo Rocca, «Formas del espionaje. Mario Levrero responde un cuestionario », en Ezequiel De Rosso, op. cit., p. 98.

15. $C f$. al respecto, Almuth Grésillon, Eléments de critique génétique. Lire les manuscrits modernes, París : PUF, 1994 ; Philippe Willemart, Critique génétique : pratiques et théorie. París : L'Harmattan, 2007.

16. Mario Levrero, Irrupciones, Montevideo : Criatura, 2013, p. 43.

17. Cf. Anne Herschberg Pierrot, Le style en mouvement. Littérature et art, París: Belin, 2005, p. $121-140$.

18. Roland Barthes, La préparation du roman I et II, París : Seuil, 2003, p. 199 y 203.

19. Sergio Chejfec, « Lápices y angustias », en Ezequiel De Rosso, op. cit., p. 193

20. Adriana Astutti, « Escribir para después : Mario Levrero », en Ibid., p. 202.

21. Pablo Sila Olazabal, op. cit., p. 95, Roland Barthes, op. cit., p. 341.

22. Mario Levrero, El discurso vacío, Buenos Aires : Interzona, 2006, p. 37.

23. Diego Vecchio, "La caligrafía del sueño" en Carina González (ed.), Fuera del canon. Escrituras excéntricas de América Latina. Pittsburgh : Instituto Internacional de Literatura Iberoamericana, 2014.

24. Roland Barthes, op. cit., p. 328.

25. Cf. Anne Herschberg Pierrot, op. cit., p. 141-180.

26. Mario Levrero, La novela luminosa, Barcelona : Debolsillo, 2008.

27. Bernhild Boie, y Daniel Ferrer, Genèses du roman contemporain: incipit et entrée en écriture, París : CNRS, 1993, p. 23.

28. Mario Levrero, El discurso vacío, op. cit., p. 31.

29. Cf. Almuth Grésillon, op. cit., p. 25.

30. Antoine Compagnon, "Disproportion de Proust: les carnets de la Recherche", en Carnets d'écrivains, AAVV, París : CNRS, 1990, p. 153-158.

31. Mario Levrero, « Apuntes bonaerenses » en El portero y el otro, Montevideo : Arca, 1992, p. 119.

32. Ana Inés Larre Borges, «Bajo sospecha. Idea Vilariño y un Diario reescrito », Manuscrítica n - 24, 2013, p. 92-103.

33. Roland Barthes, op. cit., p. 201-237.

34. Jean Laplanche, op. cit., p. 138.

35. Jean Levaillant, «Inachèvement, invention, écriture » en AAVV, Le manuscrit inachevé. Ecriture, Création, Communication, París CNRS, 1986, p. 101. Véase también : Adriana Astutti, op. cit.

36. Jean Levaillant, «Inachèvement, invention, écriture » en AAVV, Le manuscrit inachevé. Ecriture, Création, Communication, París CNRS, 1986, p. 101. Véase también : Adriana Astutti, op. cit.

37. Jacques Neefs, "Stendhal, sans fin", en AAVV, Le Manuscrit inachevé. Écriture, création, communication, París : CNRS, 1986, p. 19.

38. Pierre-Marc de Biasi, «Flaubert et la poétique du non-finito », Ibid., p. 51.

39. Edward Saïd, Beginnings. Intention \& method, New York: Columbia University Press, 1985, p. 43.

40. Franz Kafka, Diarios (1910-1923), Barcelona : Tusquets, 1995, p. 32.

41. Mario Levrero, « Apuntes bonaerenses », op. cit., p. 117. 


\section{RESÚMENES}

La imagen de la puerta, representada o metafórica, permite recorrer la dinámica esencial que caracteriza la obra de Levrero, precisando su posición existencial de autor : un escritor que se sitúa en el umbral de un texto futuro. Efectivamente, sea en la dinámica espacial de los primeros textos o en la constante puesta en escena de una escritura que no deja de comenzar, constatamos esta proyección, omnipresente, hacia una obra ideal y quimérica de superación. En el artículo me concentro en algunos textos (El lugar, Desplazamientos, La novela luminosa) para proponer una mirada panorámica que subraye una continuidad allí donde algunos vieron rupturas frontales. Estas temáticas permiten también ilustrar una obsesión contemporánea con los comienzos porque que en Levrero se cristaliza un tipo de respuesta frente a la desorientación de los creadores actuales, ya identificable en Juan Emar y Macedonio Fernández: sólo escribir comienzos, concentrarse en una promesa textual nunca cumplida, siempre renovada.

L'image de la porte, représentée ou métaphorique, permet de parcourir la dynamique essentielle qui caractérise l'œuvre de Levrero et de préciser sa position existentielle d'auteur : un écrivain qui se trouve sur le seuil d'un texte à venir. En effet, que ce soit dans la dynamique spatiale des premiers textes ou dans la constante mise en scène d'une écriture qui ne cesse pas de commencer, on constate cette projection, omniprésente, vers une œuvre idéale et chimérique de dépassement. Dans l'article je me concentre sur quelques textes (El lugar, Desplazamientos, La novela luminosa) pour proposer un regard panoramique qui souligne une continuité là où certains ont $\mathrm{vu}$ des ruptures frontales. Ces thématiques permettent aussi d'illustrer une obsession contemporaine avec les commencements. Chez Levrero se cristallise un type de réponse face à la désorientation des créateurs actuels qui était déjà présente dans Juan Emar et Macedonio Fernández: n'écrire que des débuts, se concentrer dans une promesse textuelle jamais réalisée, toujours renouvelée.

The image of the door, either literal or metaphorical, allows us to explore of the fundamental dynamism that characterizes the oeuvre of Levrero and to specify his existential position as author: a writer who finds himself on the threshold of a text to come. In fact, whether it be through the spatial dynamic of the first texts or through the continual mise-en-scène of writing that never ceases to begin, we observe the omnipresent projection of self towards an ideal and chimeric oeuvre of surpassing. In the article, I focus on several texts (El Lugar, Desplazamientos, La Novela Luminosa) to suggest a panoramic view that underlines continuity in places where some have seen full-on rupture. These thematics also allow the illustration of a contemporary obsession with beginnings. In Levrero's work, a response, already present in the work of Juan Emar and Macedonio Fernández, to the disorientation of current creators crystalizes : to only write beginnings, to focus on a never-realized textual promise that is still being made. 
ÍNDICE

Keywords: beginnings, modern novel, staging of writing

Mots-clés: commencements, roman moderne, mise en scène de l'écriture, Mario Levrero

Palabras claves: comienzos, novela moderna, puesta en escena de la escritura

\section{AUTOR}

JULIO PREMAT

Université Paris 8 